\title{
Primary Prevention of Sudden Cardiac Death in Patients with Heart Failure: How Effective is Current Pharmacologic Therapy?
}

\author{
Juan J Gavira', Ignacio García-Bolao' ${ }^{1}$ and Javier Díez ${ }^{1,2 *}$
}

${ }^{1}$ Department of Cardiology and Cardiac Surgery, University of Navarra Clinic, Pamplona, Spain

${ }^{2}$ Program of Cardiovascular Diseases, Centre for Applied Medical Research, University of Navarra, Pamplona, Spain

\begin{abstract}
Sudden cardiac death is the most common cause of death in the early stages of heart failure. Implantable cardioverter-defibrillator therapies substantially reduce sudden cardiac death but incur morbidity and are expensive, so are recommended only after failure of optimal medical therapy. Guidelines recommend simultaneous first-line therapy with an angiotensin converting enzyme inhibitor and a beta blocker for heart failure with reduced ejection fraction, with diuretic therapy for symptom relief. The all-cause mortality benefit of angiotensin converting enzyme inhibitors (or angiotensin receptor blockers) in this setting is largely attributable to reduced deaths related to disease progression. Addition of a beta blocker improves both all-cause survival and rates of sudden cardiac death. Where symptoms persist, introduction of a mineralocorticoid receptor antagonist is recommended and can reduce sudden cardiac death. If symptoms continue, substitution of the angiotensin converting enzyme inhibitor with the angiotensin receptor neprilysin inhibitor sacubitril/valsartan significantly reduces all-cause mortality, with the benefit arising from fewer deaths from both sudden cardiac death and worsening heart failure. Further medical interventions should be instituted in specific situations as required. Disappointingly, despite evidence-led guidelines, approximately a quarter of patients who have heart failure with reduced ejection fraction do not receive standard therapy with an angiotensin converting enzyme inhibitor and beta blocker. It remains to be seen if recent guidelines for successive interventions in the event of non-response to standard therapy are more effectively adopted.
\end{abstract}

Keywords: ACE inhibitor; Beta blocker; Drug therapy; Heart failure; Prevention; Sacubitril/Valsartan; Sudden cardiac death

\section{Introduction}

Despite improvements in survival after diagnosis of chronic Heart Failure (HF) in recent years [1], mortality remains high. A large US study recently reported a one-year mortality rate of $30 \%$ [1] and a systematic review demonstrated that five-year mortality is higher after diagnosis of HF than for either cancer or stroke [2]. Sudden Cardiac Death (SCD) is the most common cause of death in the early course of HF when symptoms are mild, exceeding deaths due to pump failure [3-5]. In a prospective observational study of 979 patients with mildto-moderate symptomatic HF managed under routine conditions, SCD accounted for $9 \%$ of all deaths over a median follow-up of 44 months [5]. A longitudinal study of $960 \mathrm{HF}$ outpatients identified SCD as the cause of $16 \%$ of all deaths over a seven-year period, with the proportion remaining relatively constant over time [6].

The introduction of Implantable Cardioverter-Defibrillator (ICD) therapies in the 1990s represented a major step forward for improving long-term survival after HF [7]. ICD devices correct left ventricular arrhythmias, lowering the risk of SCD in patients with HF with reduced Ejection Fraction (HFrEF) due to ischemic or non-ischemic heart disease $[8,9]$. A recent study has reported further significant reductions in SCD when ICD therapy was combined with cardiac resynchronization therapy in patients with non-ischemic HFrEF [10]. Although ICDs remain a mainstay of SCD prevention in HF, there is an increasing emphasis on medical management to avoid ICD intervention [11]. Moreover, implantation of an ICD is expensive and incurs periprocedural morbidity, with a risk of long-term complications, and not all patients experience a benefit. For instance, in the elderly in whom the potentially diminished lifespan and greater presence of comorbidities makes the benefit of primary prevention of SCD by ICD less certain [12]. Careful patient selection and close monitoring is essential: for example, arrhythmia may be a marker for decompensated HF with an increased risk of death after shock therapy [13]. The European Society of Cardiology (ESC) guidelines published in 2016 recommend ICDs as primary prevention only in certain categories of patients when optimal medical therapy has been prescribed for at least three months and left ventricular EF remains $\leq 35 \%$ [14].

The ESC guidelines recommend that patients with symptomatic HFrEF receive first-line therapy with an Angiotensin Converting Enzyme (ACE) inhibitor and a beta blocker, to reduce the risk of hospitalization for HF and death [14]. An Angiotensin Receptor Blocker (ARB) can be substituted if ACE inhibitors are not tolerated or are contraindicated. Additionally, a diuretic is recommended to reduce signs and symptoms of congestion [14]. If symptoms persist despite optimal use of these pharmacotherapies, a Mineralocorticoid Receptor Antagonist (MRA) can be added, after which replacement of the ACE inhibitor with the Angiotensin Receptor Neprilysin Inhibitor (ARNI) sacubitril/valsartan is advised if the patient still remains symptomatic. Use of other drugs (such as the sinoatrial node $\mathrm{I}_{f}$ current inhibitor ivabradine, hydralazine and isosorbide dinitrate, or digoxin) should be instigated in specific clinical situations. The American College of Cardiology Foundation/American Heart Association (ACCF/AHA) guideline for the management of $\mathrm{HF}$ also recommends combined treatment with an ACE inhibitor or ARB plus a beta blocker in

*Corresponding author: Javier Díez, Centre for Applied Medical Research and University of Navarra Clinic, Pio XII, 55, E-31008 Pamplona, Spain, Tel: +34 948 194 700; E-mail: jadimar@unav.es

Received September 02, 2016; Accepted September 27, 2016; Published October 03, 2016

Citation: Gavira JJ, García-Bolao I, Díez J (2016) Primary Prevention of Sudden Cardiac Death in Patients with Heart Failure: How Effective is Current Pharmacologic Therapy? Cardiovasc Pharm Open Access 5: 198. doi: 10.4172/2329-6607.1000198

Copyright: @ 2016 Gavira JJ, et al. This is an open-access article distributed under the terms of the Creative Commons Attribution License, which permits unrestricted use, distribution, and reproduction in any medium, provided the original author and source are credited. 
HFrEF, with additional therapies in specific clinical presentations [15]. Antiarrhythmic drugs, which would seem a logical means of reducing SCD due to ventricular arrhythmias, have not been shown convincingly to prevent SCD in patients with ventricular arrhythmias. However, they can improve overall mortality [16] and hence are recommended as adjunctive therapy in very selected circumstances [17].

The continuing high rate of SCD in HF, however, raises questions about the effectiveness of current strategies for avoiding SCD-and, indeed, about how well treatment guidelines are implemented in routine practice.

\section{Etiology and Diagnosis of SCD in HF}

The etiology of SCD is complex [18]. It frequently arises from electrical causes, notably ventricular arrhythmias (predominantly ventricular tachycardia) and bradycardia [14,19]. Progression from ventricular tachycardia to ventricular fibrillation is the most common terminal event, but it is often uncertain if this was the primary trigger for SCD or if fibrillation occurred secondary to myocardial ischemia, Myocardial Infarction (MI) or other events rather than from HF per se. Structural remodeling of the left ventricle, characterized by hypertrophy, dilation and fibrosis secondary to excessive activation of the Renin-Angiotensin-Aldosterone (RAAS) system increases risk of an event [20], and scar formation following MI or elevated filling pressures can induce ventricular arrhythmias in a remodeled heart. Excessive sympathetic activation is also a contributory factor, triggering imbalances in electrolyte currents which predispose the ventricular myocardium to abnormal depolarizations and arrhythmias. Less frequently, SCD is caused by coronary, cerebral or aortic vascular causes [14]. This varied etiology confounds a firm definition, but generally cardiac arrest in a patient with HF known recently to be in their usual state of health is regarded as SCD.

Diagnosing the cause of SCD can thus be difficult. It is too simplistic to equate SCD with arrhythmia, although often arrhythmia is speculatively stated as the underlying event. The high prevalence of underlying ischemic heart disease and previous MI in patients with $\mathrm{HF}$ is a major confounder. MI as the cause of SCD in patients with HF is often detected only on autopsy, but since autopsy is not always performed MI can be substantially underreported. One review of data from the ATLAS trial found that SCD was attributed to acute MI in $28 \%$ of autopsied cases compared to only $4 \%$ of non-autopsied cases [21]. Patients with SCD often die unwitnessed at home, or before they reach hospital, making diagnosis of the cause more challenging. Conversely, a severely ill patient may have death recorded as progressive HF instead of SCD. Indeed, some early clinical trials grouped death due to progressive HF and SCD in the context of deteriorating HF as the same entity [22]. These difficulties contribute to the variation in reported rates of SCD in observational studies $[5,6,23]$.

\section{RAAS Inhibition and SCD}

Upregulation of the RAAS in response to reduced cardiac output plays a key role in the development of structural and electrical remodeling in HF, and thus the development of atrial and ventricular arrhythmias [24]. Accordingly, treatment with an ACE inhibitor or ARB might be expected to reduce the rate of arrhythmia-induced SCD. Meta-analyses have confirmed that RAAS inhibition reduces the risk for atrial fibrillation across various clinical settings [25] and in HF $[26,27]$. One recent meta-analysis of 15 trials found that RAAS inhibition lowered the risk for atrial fibrillation by $25 \%$ across all indications, and by $42 \%$ in HF patients [26]. The V-HeFT II study has also demonstrated a reduction in pre-existing ventricular arrhythmias after initiation of enalapril, and a lower rate of new ventricular arrhythmias compared to hydralazine-isosorbide dinitrate, in patients with predominantly mild-to-moderate HF [28]. In terms of structural pathologies, ACE inhibitor or ARB therapy can also modulate the progression of ventricular dilation by reducing ventricular afterload and preload, reducing remodeling secondary to hemodynamic and neuroendocrine effects, and reducing risk for myocardial ischemia and MI [29]. ACE inhibitors reduce the risk of MI in high-risk patients without HF [30-32] and are recommended in asymptomatic patients with left ventricular systolic dysfunction [14]. Evidence for a significant reduction in MI for ACE inhibitors in HF is less convincing [33]. As discussed above, however, MI is likely to be underdiagnosed in the setting of HF, an effect that may partly account for this observation.

A number of major trials-including the CONSENSUS study of more than 6,000 patients [34]-have demonstrated a reduction in all-cause mortality in HF patients given an ACE inhibitor (Table 1) [22,34-36]. An effect on SCD is more complex to establish. In the CONSENSUS II study, performed in patients with severe HF, there was no difference in the rate of SCD for enalapril versus placebo; the effect of ACE inhibition was restricted to patients with progressive HF [38]. This is perhaps not unexpected given the preponderance of death due to progressive disease in more severe cases of HF. In the V-HeFT II trial, undertaken in 804 men in whom the NYHA class was II or III in $>90 \%$ of cases, two-year mortality was significantly lower under enalapril treatment than hydralazine-isosorbide dinitrate $(16 \%$ vs. $25 \%$ in controls, $p=0.015$ ) [36] and the survival benefit was largely accounted for by a decrease in SCD [28]. This observation has not been replicated in other studies, however (Table 1), and even in the cohort of enalapril-treated patients the rate of SCD exceeded $10 \%$ over a two-year period ( $10.8 \%$ vs. $16.2 \%$ with placebo, $\mathrm{p}=0.004)$ [28]. A meta-analysis of randomized, placebo-controlled trials of ACE inhibition found no significant effect on SCD or presumed arrhythmic deaths (odds ratio [OR] $0.91 ; 95 \%$ CI $0.73,1.12$ ) [33]. ACE inhibitors may reduce the risk for SCDs in non-HF patients with previous MI [39] but evidence for a reduction in SCD after MI in patients with HF or left ventricular dysfunction, is mixed $[35,40,41]$.

Fewer studies have reported SCD as an outcome measure for ARB therapy in HF. The ELITE study, which compared losartan versus captopril in patients with NYHA class II or III HF who had not previously received an ACE inhibitor, showed a lower rate of both all-cause mortality and SCD under losartan [42]. However, the far larger ELITE II study found a non-significant trend to more SCD with losartan [43], with similar findings in the OPTIMAAL trial of 5,477 patients with acute MI and HF [44]. ARBs are thus currently considered an alternative therapy in HF patients who cannot tolerate ACE inhibitors.

Overall, the all-cause mortality benefit of ACE inhibitors or ARBs in HF appears largely due to an improvement in deaths related to disease progression, with only limited evidence for a reduction in SCD [45].

\section{Beta Blockers and SCD}

Beta blockers inhibit the effect of elevated noradrenaline levels induced by sympathetic overactivation, and restrict left ventricular remodeling [20], with reduced rates of ventricular tachycardia [46] One recent meta-analysis of various beta blockers in 21 randomized trials of HF patients, 18 of which were versus placebo, found that the significant improvement in mortality observed under beta blocker therapy (OR 0.71 [95\% 0.64, 0.80] versus controls) was matched by a reduction in SCD (OR 0.73 [95\% 0.61, 0.88]) [47]. Another meta- 


\begin{tabular}{|c|c|c|c|c|c|c|c|c|c|}
\hline Study & $\begin{array}{l}\text { Mean } \\
\text { LVEFF }\end{array}$ & NYHA I/II/III/IV & $\mathbf{n}$ & $\begin{array}{c}\text { ACE } \\
\text { inhibitor }\end{array}$ & Comparator & $\begin{array}{l}\text { Protocol- } \\
\text { specified } \\
\text { adjunctive } \\
\text { medical } \\
\text { therapy }\end{array}$ & Follow-up & All-cause mortality & SCD \\
\hline SOLVD [22] & $25 \%$ & 281/1457/781/43 & 2569 & Enalapril & Placebo & None specified & $\begin{array}{l}\text { Mean } 41 \\
\text { months }\end{array}$ & $\begin{array}{l}35.2 \% \text { vs. } 39.7 \% \\
\quad(p=0.004)\end{array}$ & $\begin{array}{c}\text { No significant effect } \\
(8.2 \% \text { vs. } 8.8 \%)\end{array}$ \\
\hline CONSENSUS [34] & - & - & 253 & Enalapril & Placebo & $\begin{array}{l}\text { Digitalis } \\
\text { Diuretics }\end{array}$ & 6 months & $\begin{array}{c}26 \% \text { vs. } 44 \% \\
(p=0.001)\end{array}$ & $\begin{array}{l}\text { No significant effect } \\
(14 \% \text { vs. } 14 \%)\end{array}$ \\
\hline SAVE [35] & $31 \%^{a}$ & Not reported & 2231 & Captopril & Placebo & None specified & $\begin{array}{l}\text { Mean } 42 \\
\text { months }\end{array}$ & $\begin{array}{c}20 \% \text { vs. } 25 \% \\
(p=0.019)\end{array}$ & $\begin{array}{l}\text { No significant effect } \\
(5.6 \% \text { vs. } 6.7 \%)\end{array}$ \\
\hline V-HeFT II $[28,36]$ & $29 \%$ & $46 / 410 / 345 / 3$ & $804^{c}$ & Enalapril & $\begin{array}{c}\text { Hydralazine } \\
+ \text { isosorbide } \\
\text { dinitrate }\end{array}$ & None specified & 2 years & $\begin{array}{c}18 \% \text { vs. } 25 \% \\
(p=0.016)\end{array}$ & $\begin{array}{c}10.8 \% \text { vs. } 16.2 \% \\
\quad(p=0.024)\end{array}$ \\
\hline SOLVD [37] & $28 \%{ }^{\mathrm{b}}$ & 2821/1397/0/0 & 4228 & Enalapril & Placebo & $\begin{array}{l}\text { No drug therapy } \\
\text { for HF }\end{array}$ & $\begin{array}{c}\text { Mean } 37.4 \\
\text { months }\end{array}$ & $\begin{array}{c}14.8 \% \text { vs. } 15.8 \% \\
\quad(p=0.30)\end{array}$ & $\begin{array}{c}\text { No significant effect } \\
(4.6 \% \text { vs. } 5.0 \%)\end{array}$ \\
\hline
\end{tabular}

aAll patients had myocardial infarction 3-16 days prior to randomization; ${ }^{\mathrm{b}}$ All patients were asymptomatic; ${ }^{\mathrm{C}} \mathrm{All}$ male. LVEF: Left Ventricular Ejection Fraction; NYHA: New York Heart Association

Table 1: Sudden Cardiac Death (SCD) in key randomized, double-blind trials of Angiotensin Converting Enzyme (ACE) inhibitor therapy without concomitant beta blocker therapy.

analysis, which included only those trials which reported SCD rates and which excluded comparative trials of beta blockers versus ACE inhibitors, also showed that beta blocker therapy is associated with a similar reduction in both SCD (OR 0.69, 95\% CI 0.62, 0.77) and allcause mortality (0.67 [95\% CI 0.59-0.76] [48].

When given in combination with an ACE inhibitor, adding the anti-adrenergic effect of beta blockade to RAAS inhibition improves all-cause survival versus ACE inhibition alone, with a significant improvement for SCD demonstrated in most trials (Table 2) [46,4954]. This underpins current recommendations that patients with stable, symptomatic HFrEF receive combined therapy [14]. Beta blockers are also advised in patients with asymptomatic left ventricular systolic dysfunction with a previous MI to lower the mortality risk [14].

Although earlier initiation of beta blockade could theoretically be advantageous, since the sympathetic nervous system is activated earlier than the RAAS in HF [55], there is no convincing evidence to support monotherapy with a beta blocker prior to ACE inhibitor therapy $[4,56]$. In the CIBIS III study, where 1,010 patients with NYHA class II or III HF were randomized to bisoprolol or enalapril for six months, followed by combined therapy for up to 24 months, there was a trend to fewer SCDs under bisoprolol, but this was partly offset by more pump failure deaths compared to enalapril [4] and overall mortality was similar [56]. In the smaller CARMEN study no difference was observed for SCD between carvedilol or enalapril alone [57]. Equally, the convention of starting treatment with an ACE inhibitor followed by a beta blocker is no longer current and there is now a consensus that the two classes act in a complementary manner and should be started together as soon as HFrEF is diagnosed [14].

There does not appear to be any relevant difference between individual beta blocker drugs in terms of an effect of SCD or other mortality-related endpoints [47].

\section{Further Medication Options}

Introduction of a MRA (spironolactone or epleronone) is recommended if patients with HFrEF remain symptomatic despite treatment with an ACE inhibitor and a beta blocker [14]. Randomized trials in patients with severe HF [58], MI with left ventricular dysfunction [59] and more recently mild HF [60], in whom symptoms did not resolve with standard therapy, showed a trend to reduced SCD after addition of a MRA. The effect became significant when data were pooled [8].
ARNI therapy with sacubitril/valsartan is advised as a replacement for ACE inhibition where patients do not respond to addition of a MRA [14]. The neprilysin inhibitor sacubitril increases levels of vasoactive peptides such as natriuretic peptides and bradykinins [61,62], countering the adverse effects of neurohormonal activation including vasoconstriction, sodium retention and maladaptive remodeling. The ARNI sacubitril/valsartan combines neprilysin inhibition with RAAS inhibition, and has been shown in the doubleblind randomized PARADIGM trial of 8,442 patients with HFrEF to reduce all-cause mortality significantly compared to enalapril [63]. A subsequent analysis of the mode of death in PARADIGM showed that the mortality benefit was derived both from fewer deaths due to SCD and to worsening HF (Figure 1) [64].

Additionally, but with weaker levels of evidence, the sinus node inhibitor ivabradine [33] and hydralazine with isosorbide dinitrate $[14,15]$ can be considered in particular circumstances. Ivabradine, indicated for use in patients with symptomatic HFrEF in sinus rhythm with a resting heart rate of $70 \mathrm{bpm}$ or higher, exerts no effect on SCD rates [65]. For hydralazine-isosorbide dinitrate, an early trial showed a reduction in SCD compared to ACE inhibition [36], but data on its effect when combined with contemporary therapy are lacking.

\section{Medical Intervention on SCD in the Real World}

Key recommendations for medical management of symptomatic HF are still not applied universally. Even ACE inhibitors-the cornerstone of management for more than 25 years-are not prescribed in all cases of HF. An analysis of 4,605 patients with HF in 15 European countries, published in 2015, reported that $23.8 \%$ received inappropriate drug prescriptions, defined as either no ACE inhibitor or no beta blocker, or inadequate doses of either drug [66]. In the US, one large registry analysis found that only $61.1 \%$ of patients received medical therapy as per guidelines [67], while a Spanish assessment reported that betablockers and ACE inhibitors were being prescribed in $75.6 \%$ and 53.4\% of patients with HFrEF [68]. ESC guidelines recommend that both ACE inhibitors and beta blockers should be up-titrated to the maximum tolerated dose [14] in view of evidence for a dose-related association with mortality, particularly for beta blocker therapy [54] but also, to a lesser extent, for ACE inhibitors $[69,70]$. Obtaining data on whether dosing is being optimized is challenging since the dose must be individualized in each case, but the available evidence is not encouraging [66,71]. 

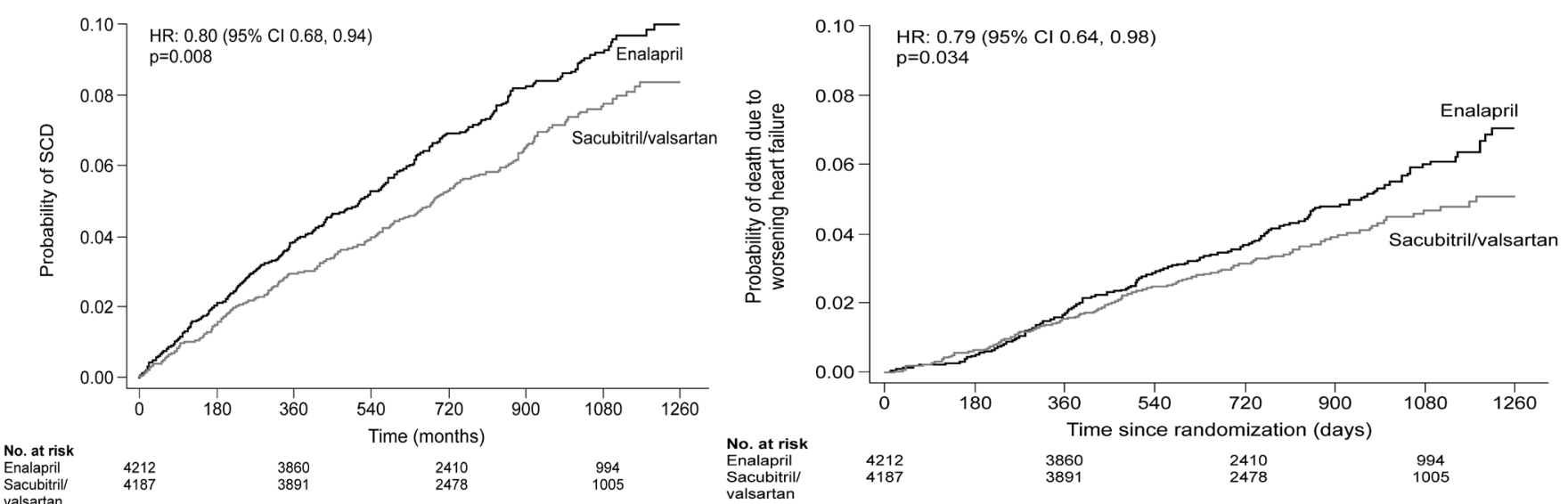

Figure 1: (a) Sudden cardiac death [SCD] and (b) death due to worsening HF in the randomized PARADIGM trial of sacubitril/valsartan versus enalapril in patients with HF and reduced ejection fraction (Kaplan-Meier estimates) (Reproduced with permission from Desai et al. [64]).

\begin{tabular}{|c|c|c|c|c|c|c|c|c|c|}
\hline Study & $\begin{array}{l}\text { Mean } \\
\text { LVEF }\end{array}$ & NYHA I/II/III/IV & $\mathbf{n}$ & $\begin{array}{l}\text { Beta } \\
\text { blocker }\end{array}$ & Comparator & $\begin{array}{l}\text { ACE inhibitorl } \\
\text { ARB }\end{array}$ & Follow-up & All-cause mortality & SCD \\
\hline CIBIS [46] & $\sim 25 \%$ & $0 / 0 / 609 / 32$ & 641 & Bisoprolol & Placebo & $90 \%$ & $\begin{array}{l}\text { Mean } 1.9 \\
\text { years }\end{array}$ & $\begin{array}{c}16.6 \% \text { vs. } 20.8 \% \\
(p=0.22)\end{array}$ & $\begin{array}{l}5.3 \% \text { vs. } 5.3 \% \\
\text { (n.s.) }^{\mathrm{a}}\end{array}$ \\
\hline CIBIS II [49] & $28 \%$ & 0/0/2202/445 & 2647 & Bisoprolol & Placebo & $96 \%$ & $\begin{array}{l}\text { Mean } 1.3 \\
\text { years }\end{array}$ & $\begin{array}{c}11.8 \% \text { vs. } 17.3 \% \\
(p<0.001)\end{array}$ & $\begin{array}{l}3.6 \% \text { vs. } 6.3 \% \\
\quad(p=0.001)\end{array}$ \\
\hline MERIT-HF $[50,51]$ & $28 \%$ & 0/1636/2225/144 & 3991 & Metoprolol & Placebo & $\sim 90 \%$ & $\begin{array}{l}\text { Mean } 12 \\
\text { months }\end{array}$ & $\begin{array}{c}7.2 \% \text { vs. } 11.0 \% \text { per } \\
\text { patient year }(p<0.001)\end{array}$ & $\begin{array}{l}4.2 \text { vs. } 6.6 \% \\
(p<0.001)\end{array}$ \\
\hline $\begin{array}{l}\text { COPERNICUS } \\
{[52,53]}\end{array}$ & $20 \%$ & All IV & 2289 & Carvedilol & Placebo & $97 \%$ & $\begin{array}{l}\text { Mean } 10.4 \\
\text { months }\end{array}$ & $\begin{array}{c}11.2 \% \text { vs. } 16.8 \% \\
(p<0.001)\end{array}$ & $\begin{array}{c}3.9 \% \text { vs. } 6.1 \% \\
(0.016)\end{array}$ \\
\hline MOCHA [54] & $23 \%$ & $0 / 75 / 86 / 4$ & 345 & Carvedilol $^{\mathrm{b}}$ & Placebo & $\sim 93 \%$ & 6 months & $\begin{array}{c}4.6 \% \text { vs. } 15.5 \% \\
(p<0.001)\end{array}$ & $\begin{array}{l}2.3 \% \text { vs. } 7.1 \% \\
\quad(p=0.035)\end{array}$ \\
\hline
\end{tabular}

a $5.9 \%$ vs. $7.5 \%$ for a combined endpoint of sudden death and deaths with documented ventricular tachycardia or fibrillation; ${ }^{\circ}$ Three randomized groups $(5.25,12.5$ and 25 mg carvedilol). LVEF: Left Ventricular Ejection Fraction; n.s: Non-Significant; NYHA: New York Heart Association

Table 2: Sudden Cardiac Death (SCD) in key randomized, double-blind trials of beta blocker therapy with an Angiotensin Converting Enzyme (ACE) inhibitor or Angiotensin Receptor Antagonist (ARB).

\section{Conclusion}

SCD remains a major source of mortality in HF, particularly in the early stages. A focus on lowering the risk for SCD must, of course, take into account the competing risks to which HF patients are exposed. Any reduction in SCD could potentially increase risk of death from progressive heart disease if there is no effect on the underlying pathology. SCD tends to occur earlier than deaths due to pump failure [72] so a reduction in SCD could extend life expectancy. Nevertheless, lower rates of SCD are only meaningful if achieved in the context of an overall reduction in mortality. Current guidelines recommend that all symptomatic patients with HFrEF receive combination therapy with an optimally-dosed ACE inhibitor and beta blocker, with a succession of further medical therapies to be instituted in the event of non-response or intolerance. This management pathway prioritises a reduction in allcause mortality, but would also be expected to achieve a reduction in SCD, largely due to beta blockade and, in the event of non-response to adjunctive MRA treatment, use of sacubitril/valsartan. The importance of pursuing this pathway rigorously, in contrast to simply starting an ACE inhibitor with or without a beta blocker, is evident. Even in controlled trials of combined therapy, with protocol-driven prescribing and dosing patterns, as many as $4 \%$ of patients with mild-to-moderate HF die from SCD per year [51]. Disappointingly, the available data suggest that approximately one in four HF patients does not receive both an ACE inhibitor and a beta blocker, even though it is several years since the combination was established as best practice. It remains to be seen if the recent ESC guidelines [14], including simultaneous initiation of beta blockers and ACE inhibition for symptomatic HF, and progression to a MRA or sacubitril/valsartan if symptoms persist, are more effectively adopted.

A growing advocacy now encourages the use of systematic ventricular assist devices in ambulatory HF patients, on the basis of the misconception that the clinical response to medical therapy is poor. However, annual mortality rates in HF patients with mild-to-moderate symptoms and normal renal function, especially in non-ischemic heart disease have now fallen to below 5\% [73]. It is therefore important to emphasize that effective medical therapy in patients with HF in fact modifies the clinical course of the disease, including SCD, and that HF physicians must seek to optimize medical intervention in all patients [74].

\section{Disclosures}

Javier Diez has served as an advisor and/or as a speaker for Novartis, Bayer, Merck, Sharp and Dohme, and Sarfez Pharmaceuticals Inc. Ignacio Garcia-Bolao has served as an advisor, proctor and/or as a speaker for Saint Jude Medical and Boston Scientific.

\section{References}

1. Chen J, Normand SL, Wang Y, Krumholz HM (2011) National and regional trends in heart failure hospitalization and mortality rates for Medicare beneficiaries, 1998-2008. JAMA 306: 1669-1678.

2. Askoxylakis V, Thieke C, Pleger ST, Most P, Tanner J, et al. (2010) Long-term survival of cancer patients compared to heart failure and stroke: a systematic review. BMC Cancer 10: 105. 
Citation: Gavira JJ, García-Bolao I, Díez J (2016) Primary Prevention of Sudden Cardiac Death in Patients with Heart Failure: How Effective is Current Pharmacologic Therapy? Cardiovasc Pharm Open Access 5: 198. doi: 10.4172/2329-6607.1000198

Page 5 of 6

3. Rho RW, Patton KK, Poole JE, Cleland JG, Shadman R, et al. (2012) Important differences in mode of death between men and women with heart failure who would qualify for a primary prevention implantable cardioverter-defibrillator. Circulation 126: 2402-2407.

4. Krum H, van Veldhuisen D, Funck-Brentano C, Vanoli E, Silke B, et al. (2011) Effect on mode of death of heart failure treatment started with bisoprolol followed by Enalapril, compared to the opposite order: results of the randomized CIBIS III trial. Cardiovasc Ther 29: 89-98.

5. Gastelurrutia P, Pascual-Figal D, Vazquez R, Cygankiewicz I, Shamagian LG et al. (2011) Obesity paradox and risk of SCD in heart failure results from the MUerte Subita en Insuficiencia Cardiaca (MUSIC) study. Am Heart J 161: 158164

6. Pons F, Lupón J, Urrutia A, González B, Crespo E, et al. (2010) Mortality and cause of death in patients with heart failure: findings at a specialist multidisciplinary heart failure unit. Rev Esp Cardiol 63: 303-314.

7. Sengupta J, Abdelhadi R (2013) Approach to reduction of ventricular arrhythmias and implantable cardioverter-defibrillator therapies in patients with heart failure. Curr Opin Cardiol 28: 337-343.

8. Peck KY, Lim YZ, Hopper I, Krum H (2014) Medical therapy versus implantable cardioverter-defibrillator in preventing sudden cardiac death in patients with left ventricular systolic dysfunction and heart failure: a meta-analysis of $>35,000$ patients. Int J Cardiol 173: 197-203.

9. Theuns DA, Smith T, Hunink MG, Bardy GH, Jordaens L (2010) Effectiveness of prophylactic implantation of cardioverter-defibrillators without cardiac resynchronization therapy in patients with ischaemic or non-ischaemic heart disease: a systematic review and meta-analysis. Europace 12: 1564-1570.

10. Køber L, Thune JJ, Nielsen JC, Haarbo J, Videbæk L, et al. (2016) Defibrillator implantation in patients with nonischemic systolic heart failure. N Engl J Med 375: 1221-1230.

11. Marangou J, Paul V (2015) Current attitudes on cardiac devices in heart failure: a review. Clin Ther 37: 2206-2214.

12. Tung P, Alpert CM (2013) Causes and prevention of sudden cardiac death in the elderly. Nat Rev Cardiol 10: 135-142.

13. Chandrasekaran B, Cowburn PJ (2010) Heart failure: the challenge of selecting patients for implantable cardioverter defibrillation therapy. Expert Rev Med Devices 7: 461-467.

14. Ponikowski P, Voors AA, Anker SD, Bueno H, Cleland JG, et al. (2016) 2016 ESC guidelines for the diagnosis and treatment of acute and chronic heart failure. Eur Heart J 37: 2129-2200.

15. Yancy CW, Jessup M, Bozkurt B, Butler J, Casey DE Jr, et al. (2013) 2013 ACCF/AHA guideline for the management of heart failure: a report of the American College of Cardiology Foundation/American Heart Association Task Force on Practice Guidelines. J Am Coll Cardiol 62: e147-e239

16. Weeks PA, Sieg A, Gass JA, Rajapreyar I (2016) The role of pharmacotherapy in the prevention of sudden cardiac death in patients with heart failure. Heart Fail Rev 21: 415-431.

17. Priori SG, Blomström-Lundqvist $C$, Mazzanti A, Blom N, Borggrefe $M$, et al. (2015) 2015 ESC Guidelines for the management of patients with ventricular arrhythmias and the prevention of sudden cardiac death. The Task Force for the Management of Patients with Ventricular Arrhythmias and the Prevention of Sudden Cardiac Death of the European Society of Cardiology (ESC). Endorsed by: Association for European Paediatric and Congenital Cardiology (AEPC). Eur Heart J 36: 2793-2867.

18. Johnson FL (2014) Pathophysiology and etiology of heart failure. Cardiol Clin 32: 9-19.

19. Cleland JGF, Massie BM, Packer M (1999) Sudden death in heart failure: vascular or electrical? Eur J Heart Failure 1: 41-45.

20. Adamson PB, Gilbert EM (2006) Reducing the risk of sudden death in heart failure with beta-blockers. J Card Fail 12: 734-746.

21. Uretsky B, Thygesen K, Armstrong PW, Cleland JG, Horowitz JD, et al. (2000) Acute coronary findings at autopsy in heart failure patients with SCD: results from the assessment of treatment with lisinopril and survival (ATLAS) trial. Circulation 102: 611-616.

22. SOLVD Investigators (1991) Effect of enalapril on survival in patients with reduced left ventricular ejection fractions and congestive heart failure. $\mathrm{N}$ Engl
J Med 325: 293-302.

23. Vazquez R, Bayes-Genis A, Cygankiewicz I, Pascual-Figal D, GrigorianShamagian L, et al. (2009) The MUSIC Risk score: a simple method for predicting mortality in ambulatory patients with chronic heart failure. Eur Heart J 30: 1088-1096.

24. Makkar KM, Sanoski CA, Spinler SA (2009) Role of angiotensin-converting enzyme inhibitors, angiotensin II receptor blockers, and aldosterone antagonists in the prevention of atrial and ventricular arrhythmias. Pharmacotherapy 29: 31-48.

25. Zhao D, Wang ZM, Wang LS (2015) Prevention of atrial fibrillation with reninangiotensin system inhibitors on essential hypertensive patients: a metaanalysis of randomized controlled trials. J Biomed Res 29: 475-485.

26. Huang G, Xu JB, Liu JX, He Y, Nie XL et al. (2011) Angiotensin-converting enzyme inhibitors and angiotensin receptor blockers decrease the incidence of atrial fibrillation: a meta-analysis. Eur J Clin Invest 41: 719-733.

27. Schneider MP, Hua TA, Böhm M, Wachtell K, Kjeldsen SE, et al. (2010) Prevention of atrial fibrillation by Renin-Angiotensin system inhibition a metaanalysis. J Am Coll Cardiol 55: 2299-2307.

28. Fletcher RD, Cintron GB, Johnson G, Orndorff J, Carson P, et al. (1993) Enalapril decreases prevalence of ventricular tachycardia in patients with chronic congestive heart failure. The V-HeFT II VA Cooperative Studies. Circulation 87: V149-V155.

29. Cleland JG, Puri S (1994) How do ACE inhibitors reduce mortality in patients with left ventricular dysfunction with and without heart failure: remodelling, resetting, or sudden death? Br Heart J 72: S81-S86.

30. Savarese G, Costanzo P, Cleland JG, Vassallo E, Ruggiero D, et al. (2013) A meta-analysis reporting effects of angiotensin-converting enzyme inhibitors and angiotensin receptor blockers in patients without heart failure. J Am Coll Cardiol 61: 131-142.

31. McAlister FA, Renin Angiotension System Modulator Meta-Analysis Investigators (2012) Angiotensin-converting enzyme inhibitors or angiotensin receptor blockers are beneficial in normotensive atherosclerotic patients: a collaborative meta-analysis of randomized trials. Eur Heart J 33: 505-514.

32. Al-Mallah MH, Tleyjeh IM, Abdel-Latif AA, Weaver WD (2006) Angiotensinconverting enzyme inhibitors in coronary artery disease and preserved left ventricular systolic function: a systematic review and meta-analysis of randomized controlled trials. J Am Coll Cardiol 47: 1576-1583.

33. Garg R, Yusuf S (1995) Overview of randomized trials of angiotensin-converting enzyme inhibitors on mortality and morbidity in patients with heart failure. Collaborative Group on ACE Inhibitor Trials. JAMA 273: 1450-1456.

34. The Consensus Trial Study Group (1987) Effects of enalapril on mortality in severe congestive heart failure. Results of the Cooperative North Scandinavian Enalapril Survival Study (CONSENSUS). N Engl J Med 316: 1429-1435.

35. Pfeffer MA, Braunwald E, Moye LA, Basta L, Brown EJ Jr, et al. (1992) Effect of captopril on mortality and morbidity in patients with left ventricular dysfunction after myocardial infarction. Results of the survival and ventricular enlargement trial. The SAVE Investigators. N Engl J Med 327: 669-677.

36. Cohn JN, Johnson G, Ziesche S, Cobb F, Francis G, et al (1991) A comparison of enalapril with hydralazine-isosorbide dinitrate in the treatment of chronic congestive heart failure. N Engl J Med 325: 303-310.

37. The SOLVD Investigators (1992) Effect of enalapril on mortality and the development of heart failure in asymptomatic patients with reduced left ventricular ejection fractions. N Engl J Med 327: 685-691.

38. Swedberg K, Held P, Kjekshus J, Rasmussen K, Rydén L, et al. (1992) Effects of the early administration of enalapril on mortality in patients with acute myocardial infarction. Results of the Cooperative New Scandinavian Enalapril Survival Study II (CONSENSUS II). N Engl J Med 327: 678-684.

39. Domanski MJ, Exner DV, Borkowf CB, Geller NL, Rosenberg Y, et al. (1999) Effect of angiotensin converting enzyme inhibition on sudden cardiac death in patients following acute myocardial infarction. A meta-analysis of randomized clinical trials. J Am Coll Cardiol 33: 598-604.

40. Cleland JG, Erhardt L, Murray G, Hall AS, Ball SG (1997) Effect of ramapril on morbidity and mode of death among survivors of acute myocardial infarction with clinical evidence of heart failure. A report from the AIRE Study Investigators. Eur Heart J 18: 41-51.

41. Køber L, Torp-Pedersen C, Carlsen JE, Bagger H, Eliasen P, et al. (1995) A clinical trial of the angiotensin-converting-enzyme inhibitor trandolapril in 
patients with left ventricular dysfunction after myocardial infarction. Trandolapril Cardiac Evaluation (TRACE) Study Group. N Engl J Med 333: 1670-1676.

42. Pitt B, Segal R, Martinez FA, Meurers G, Cowley AJ, et al. (1997) Randomised trials of losartan versus captopril in patients over 65 with heart failure (Evaluation of Losartan in the Elderly Study, ELITE). Lancet 349: 747-752.

43. Pitt B, Poole-Wilson PA, Segal R, Martinez FA, Dickstein K, et al. (2000) Effect of losartan compared with captopril on mortality in patients with symptomatic heart failure: randomised trial--the Losartan Heart Failure Survival Study ELITE II. Lancet 355: 1582-1587.

44. Naccarella F, Naccarelli GV, Maranga SS, Lepera G, Grippo MC, et al. (2002) Do ACE inhibitors or angiotensin II antagonists reduce total mortality and arrhythmic mortality? A critical review of controlled clinical trials. Curr Opin Cardiol 17: 6-18.

45. Dickstein K, Kjekshus J, OPTIMAAL Steering Committee of the OPTIMAAL Study Group (2002) Effects of losartan and captopril on mortality and morbidity in high-risk patients after acute myocardial infarction: the OPTIMAAL randomised trial. Optimal Trial in Myocardial Infarction with Angiotensin II Antagonist Losartan. Lancet 360: 752-760.

46. [No authors listed] (1994) A randomized trial of beta-blockade in heart failure The Cardiac Insufficiency Bisoprolol Study (CIBIS). CIBIS Investigators and Committees. Circulation 90: 1765-1773.

47. Chatterjee S, Biondi-Zoccai G, Abbata A, D'Ascenzo F, Castagno D, et al. (2013) Benefits of $\beta$ blockers in patients with heart failure and reduced ejection fraction: network meta-analysis. BMJ 346: 555.

48. Al-Gobari M, El Khatib C, Pillon F, Gueyffier F (2013) $\beta$-blockers for the prevention of sudden cardiac death in heart failure patients: a meta-analysis of randomized controlled trials. BMC Cardiovasc Disord 13: 52.

49. [No authors listed] (1999) The Cardiac Insufficiency Bisoprolol Study II (CIBISII): a randomised trial. Lancet 353: 9-13.

50. [No authors listed] (1999) Effect of metoprolol CR/XL in chronic heart failure: Metoprolol CR/XL Randomised Intervention Trial in Congestive Heart Failure (MERIT-HF). Lancet 353: 2001-2007.

51. Hjalmarson A, Goldstein S, Fagerberg B, Wedel H, Waagstein F, et al. (2000) MERIT-HF Study Group. Effects of controlled-release metoprolol on total mortality, hospitalizations, and wellbeing in patients with heart failure: the Metoprolol CR/XL Randomized Intervention Trial in congestive Heart Failure (MERIT-HF). JAMA 283: 1295-1302.

52. Packer M, Coats AJ, Fowler MB, Katus HA, Krum H, et al. (2001) Effect of carvedilo on survival in severe chronic heart failure. N Engl J Med 344: 1651-1658.

53. Packer M, Fowler MB, Roecker EB, Coats AJ, Katus HA, et al. (2002) Effect of carvedilol on the morbidity of patients with severe chronic heart failure: results of the Carvedilol Prospective Randomized Cumulative Survival (COPERNICUS) Study. Circulation 106: 2194-2199.

54. Bristow MR, Gilbert EM, Abraham WT, Adams KF, Fowler MB, et al. (1996) Carvedilol produces dose-related improvements in left ventricular function and survival in subjects with chronic heart failure. MOCHA Investigators. Circulation 94: $2807-2816$

55. Packer M (1992) Pathophysiology of heart failure. Lancet 340: 88-95.

56. Willenheimer R, van Veldhuisen DJ, Silke B, Erdmann E, Follath F, et al. (2005) Effect on survival and hospitalization of initiating treatment for chronic heart failure with bisoprolol followed by enalapril, as compared with the opposite sequence: results of the randomized Cardiac Insufficiency Bisoprolol Study (CIBIS) III. Circulation 112: 2426-2435.

57. Komajda M, Lutiger B, Madeira H, Thygesen K, Bobbio M, et al. (2004) Tolerability of carvedilol and ACE-Inhibition in mild heart failure. Results of CARMEN (Carvedilol ACE-Inhibitor Remodelling Mild CHF Evaluation). Eur J Heart Fail 6: 467-475.

58. Pitt B, Zannad F, Remme W, Cody R, Castaigne A, et al. (1999) The effect of spironolactone on morbidity and mortality in patients with severe heart failure. Randomized Aldactone Evaluation Study Investigators. N Engl J Med 341: 709717

59. Pitt B, Remme W, Zannad F, Neaton J, Martinez F, et al. (2003) Eplerenone, a selective aldosterone blocker, in patients with left ventricular dysfunction after myocardial infarction. N Engl J Med 348: 1309-1321.

60. Zannad F, McMurray JJ, Krum H, van Veldhuisen DJ, Swedberg K, et al. (2011) Eplerenone in patients with systolic heart failure and mild symptoms. $N$ Engl
Med 364: 11-21.

61. Cruden NH, Fox KA, Ludlam CA, Johnston NR, Newby DE (2004) Neutra endopeptidase inhibition augments vascular actions of bradykinin in patients treated with angiotensin-converting enzyme inhibition. Hypertension 44: 913918.

62. Rademaker MT, Charles CJ, Espiner EA, Nicholls MG, Richards AM, et al (1996) Neutral endopeptidase inhibition: augmented atrial and brain natriuretic peptide, haemodynamic and natriuretic responses in ovine heart failure. Clin Sci (Lond) 91: 283-291.

63. McMurray JJ, Packer M, Desai AS, Gong J, Lefkowitz MP, et al. (2014) Angiotensin-neprilysin inhibition versus enalapril in heart failure. N Engl J Med 371: 993-1004.

64. Desai AS, McMurray JJ, Packer M, Swedberg K, Rouleau JL, Chen F, et al. (2015) Effect of the angiotensin-receptor-neprilysin inhibitor LCZ696 compared with enalapril on mode of death in heart failure patients. Eur Heart J 36: 1990-1997.

65. Swedberg K, Komajda M, Böhm M, Borer JS, Ford I, et al. (2010) Ivabradine and outcomes in chronic heart failure (SHIFT): a randomised placebo-controlled study. Lancet 376: 875-885.

66. Maggioni AP, Van Gool K, Biondi N, Urso R, Klazinga N, et al. (2015) Appropriateness of prescriptions of recommended treatments in organisation for economic co-operation and development health systems: findings based on the long-term registry of the European Society of Cardiology on Heart Failure. Value Health 18: 1098-1104.

67. Roth GA, Poole JE, Zaha R, Zhou W, Skinner J, et al. (2016) Use of guideline-directed medications for heart failure before cardioverter-defibrillator implantation. J Am Coll Cardiol 67: 1062-1069.

68. Franco G, Biagio F, Battista ZG, De Simone A, Stabile G, et al. (2014) ALERTHF: adherence to guidelines in the treatment of patients with chronic heart failure. J Cardiovasc Med (Hagerstown) 15: 491-497.

69. Packer M, Poole-Wilson PA, Armstrong PW, Cleland JG, Horowitz JD, et al. (1999) Comparative effects of low and high doses of the angiotensin-converting enzyme inhibitor, lisinopril, on morbidity and mortality in chronic heart failure. ATLAS Study Group. Circulation 100: 2312-2318.

70. Poole-Wilson PA, Uretsky BF, Thygesen K, Cleland JG, Massie BM, et al. (2003) Assessment of treatment with lisinopril and survival. Mode of death in heart failure: findings from the ATLAS trial. Heart 89: 42-48.

71. Juillière Y, Suty-Selton C, Riant E, Darracq JP, Dellinger A, et al. (2014) Prescription of cardiovascular drugs in the French ODIN cohort of heart failure patients according to age and type of chronic heart failure. Arch Cardiovasc Dis 107: 21-32.

72. Goldman S Johnson G, Cohn JN, Cintron G, Smith R, et al. (1993) Mechanism of death in heart failure. The Vasodilator-Heart Failure Trials. The V-HeFT VA Cooperative Studies Group. Circulation 87: V124-V131.

73. Packer M (2016) Love of angiotensin-converting enzyme inhibitors in the time of cholera. JACC Heart Fail 4: 403-408.

74. Packer M (2016) Heart failure's dark secret. Does anyone really care about optimal medical therapy? Circulation 134: 629-631. 